\title{
Suitable Scale of an Oasis in Different Scenarios in an Arid Region of China: A Case Study of the Ejina Oasis
}

\author{
Zhaoxia Ye $\mathrm{e}^{1, *, \dagger}$, Aihong $\mathrm{Fu}^{1, *}$, Shuhua Zhang ${ }^{2}$ and Yuhai Yang ${ }^{1,+}$ \\ 1 State Key Laboratory of Desert and Oasis Ecology, Xinjiang Institute of Ecology and Geography, Chinese \\ Academy of Sciences, Urumqi 830011, China; yangyh@ms.xjb.ac.cn \\ 2 Colloge of Geomatic, Xi'an Univiersity of Science and Technology, Xi'an 710054, China; \\ shuhuazhang@xust.edu.cn \\ * Correspondence: yezx@ms.xjb.ac.cn (Z.Y.); fuah@ms.xjb.ac.cn (A.F.) \\ + These authors contributed equally to this work.
}

Received: 15 February 2020; Accepted: 24 March 2020; Published: 25 March 2020

check for updates

\begin{abstract}
The main objective of this work is to calculate the suitable scale of the Ejina Oasis in different scenarios (high-, normal-, and low-flow years), assess the stability of the Ejina Oasis, and, finally, accurately determine if an artificial oasis area and total oasis area need to be reduced or increased. Using the water balance method, we calculated the suitable scale of the artificial Ejina Oasis as $767.80,624.00$, and $451.33 \mathrm{~km}^{2}$ in high-, normal-, and low-flow years, respectively. By utilizing the water-heat balance method combined with an assessment of the present stability of the Ejina Oasis, the results showed that in high-flow years, the suitable scale of the Ejina Oasis is $1174-1762 \mathrm{~km}^{2}$, and the stability index of the current oasis is 0.55 . In normal-flow years, the suitable scale of the Ejina Oasis is found to be $915-1373 \mathrm{~km}^{2}$, and the stability index of the current oasis is 0.43 . In low-flow years, the suitable scale of the Ejina Oasis is $590-885 \mathrm{~km}^{2}$, and the stability index of the current oasis decreases to 0.27 . In order to further improve the stability of oases, it remains necessary to control the scale of oases to cope with water resource shortages that result from water resource instability under climate change. The present study's findings will enable optimal water-use planning decisions that take social, economic, and ecological issues into account, and provide the foundation for optimal decision-making for regional administrative departments to effectively coordinate regional economic development, farmland protection, environmental protection, and water resource protection.
\end{abstract}

Keywords: suitable scale of an oasis; Heihe River Basin; water balance; water-heat balance; stability index

\section{Introduction}

An oasis, in a modern economic sense, refers to a place in the desert where agriculture and animal husbandry are developed naturally or through artificial irrigation [1]. Oases can be divided into natural oases and artificial oases [2,3]. An artificial oasis is also called an irrigation oasis, which is an irrigation agricultural area or other economic activity center formed by the construction of water conservancy facilities. In a natural state, an oasis and the desert background in an arid area exist in a state of competitive equilibrium [1]. However, soil nutrient depletion and excessive agricultural production have greatly disrupted the natural balance. As a result, the development capacity of villages has fallen and threatened their sustainability and resilience [4]. Consequently, many serious ecological environmental problems have emerged, in which downstream river basin areas have atrophied or disappeared, terminal lakes dried up, water quality deteriorated, and land has experienced rapid desertification [5]. These geological results also negatively impacted the economic and social stability of affected arid areas. Therefore, the sustainable development of oases has been paid more and more 
attention to by scientists. Huang et al. [6] analyzed the landscape pattern and ecological security trend of a modern oasis in Xinjiang in order to maintain the stability of the oasis. Luedeling and Buerkert [7] studied the impact of land use change on hydrological sustainability in the oasis in the Northern mountains of Oman. The results showed that land use change increased the demand for water and put pressure on the water balance in the oasis. Zhang et al. [8] studied the evolution of an oasis and the utilization of water resources in Manas River Valley. Their purpose was to solve the contradiction between the continuous expansion of the oasis and the shortage of water resources, so as to maintain the sustainable development of Manas River Valley. Abdel Kawy and Darwish [9] assessed the optimal land use and water demand for agricultural land in some soils of the South Paris Oasis in the Western desert of Egypt, with the aim of achieving land adaptability and water use efficiency and determining the optimal land use system. Massone et al. [10] used isotope technology to study the contribution of snowmelt to the sustainability of the Mendoza irrigation oasis in Argentina. Xue et al. [11] took the Southern part of the Taklimakan Desert as an example to analyze the influence of different weather events on the micro-climate of the oasis and discuss the significance of maintaining the sustainability of the oasis. Tenza et al. [12] explored the sustainability of ecosystems in small and medium-sized societies in arid environments. Although these researches take different angles, their purpose is to maintain the stability of oases and promote the sustainable development of oases.

The oasis development means that the policy makers must face the following practical problems: does the expansion of oasis scales threaten the natural environment on which human beings depend for survival and development, and aggravate the process of desertification? Does the expansion of artificial oases affect the development of natural oases? Are current oases stable in scale? In order to safeguard the ecological, social, and economic survival and prosperity of arid areas, these questions urgently require answers. From these practical problems, we find the scientific problem and significance of this research, which is to determine the suitable scale of a typical oasis, so as to maintain the stable and sustainable development of oases.

A suitable oasis is an oasis that has a suitable scale determined with a scientific approach. Due to the major impacts of achieving or not achieving suitable oases, this topic has attracted increased attention from researchers, academics, and regional management departments. The extant literature in this area has also provided numerous case studies and guiding bases for answering the aforementioned questions. The Ejina Oasis is an important ecological barrier in Northwest and North China. Historically, the Ejina Oasis has been able to survive and sustain itself with incoming water from the Heihe River. With the development of the social economy and increasing scale of human activities, however, the inflow of water from the Heihe River has gradually decreased. As a result, the groundwater level in the Ejina area continues to decline, the vegetation of the oasis degenerates, and ecological function decreases $[13,14]$. Water is the key factor of oasis stabilization [15]. The primary aims of the current study are to determine, under the constraint of limited water resources, precisely how to ensure the moderate development of the Ejina Oasis and how to optimally coordinate water resources in the area. When the total incoming water and water-saving efficiency are stable, an increase of irrigated area means an increase of irrigation water use for irrigation, which inevitably leads to a reduction of water consumption for human economic activity and the natural oasis. This requires regional management departments to augment water-saving efficiency, meet the needs of irrigation, and take the water used for social and economic activities into account.

At present, international research on the suitable scales of oases is relatively scarce. However, domestic researchers within China are paying increasing attention to varied theories and methods to determine the suitable sizes of oases. For example, considering the characteristics of artificial oasis development and the elements of oasis stability in an arid inland river area of China, Wang et al. [16] proposed a green index of oases and a calculation methodology to evaluate oasis stability in terms of modern economic significance and the direction of oases' development and utilization. This method has been adopted by numerous scholars. For instance, Li et al. [17] estimated the suitable scale of an oasis and cultivated area in the Hotan River Basin using the water balance method and water-heat 
balance model. Ling et al. [18] analyzed the suitable scale of an oasis in the Keriya River Basin under different guaranteed degrees of water resources, as well as water resource demand, to maintain natural oasis stability in the downstream of the Keriya River Basin. In this work, both the $Z$ index method and the water-heat balance model were utilized. Cao et al. [19] analyzed the suitable oasis scale of the lower reaches of the Tarim River and the suitable cultivated area based on the principle of the water-heat balance. The results showed that the instability of the oasis resulted from the existence of too much cultivated land. Chen and Chen [20] assumed that the oasis structure was layered and circular and could be divided into three layers. They estimated the suitable oasis scale and cultivated area in four sources of flow and downstream areas of the Tarim River Basin according to the principle of the water-heat balance. Ling et al. [21] evaluated the suitable oasis scale in the Manas River Basin with the water-heat balance model. Lei et al. [22] calculated suitable scales of oases in the Keriya River Basin with the water quantity balance model. Yao et al. [23] evaluated the suitability of an oasis scale in Yutian by establishing a novel evaluation index system. Guo et al. [24] investigated the suitable scale of the natural and artificial oases of the Hotan River Basin based on water resource availability.

The above recent domestic studies on the suitable scale of oases have utilized the methods of water balance and water-heat balance. In this paper, we combine the two methods to assess the present situation of oasis stability, determine the suitable degree of the oasis scale, and calculate the suitable scale of oasis in different guaranteed degrees of water resources. Due to this, we can not only estimate the suitable scale of natural oases, but also accurately determine if an artificial oasis area and total oasis area need to be reduced or increased and, if so, by what percentage. The results will constitute the scientific basis for administrative water-resource departments in arid areas to optimally allocate water resources. The present study's findings will also enable water-use planning decisions that take social, economic, and ecological issues into account. Finally, regional administrative departments will be able to effectively coordinate regional economic development, farmland protection, environmental protection, and water resource protection.

\section{Study Area and Methods}

\subsection{Study Area}

Ejina belongs to the Alashan league of the Inner Mongolia autonomous region, which is located at the Western end of the Inner Mongolia autonomous region. It covers an area of $114,606 \mathrm{~km}^{2}$ and had a permanent resident population of 34,300 as of 2015. Most of the territory constitutes uninhabited desert area, with more than $500 \mathrm{~km}$ comprising a border defense area, which is both a strategically and ecologically important barrier in the Hexi Corridor [25]. The Ejina River is the lowest reaches of the Heihe River, with a length of $270 \mathrm{~km}$. Beginning from the Langxinshan, the Ejina River is divided into two rivers: the East River and West River, respectively (Figure 1). In the process of flowing Northward, 19 branches flow into the East Juyan Lake (EJL) and West Juyan Lake (WJL), forming the Ejina Delta [26]. The annual precipitation in the region averages only $35 \mathrm{~mm}$, but potential evaporation reaches $2300 \mathrm{~mm}$ [27]. The average annual runoff in the Langxinshan Hydrologic Station was $5.09 \times$ $10^{8} \mathrm{~m}^{3}$ from 1988 to 2015 . Within this area, the Ejina Oasis is the main location for human production and life. It is distributed in a series of lake basin depressions, such as the East and West Juyan Lake, the ancient Juyan Lake, and the ancient Rinai Lake. Moreover, the Heihe River is the only river in the Ejina Basin [28]. In this study, the Ejina Oasis mainly refers to the East and West River areas below the Langxinshan water distribution junction, excluding the ancient Rinai Lake area. 

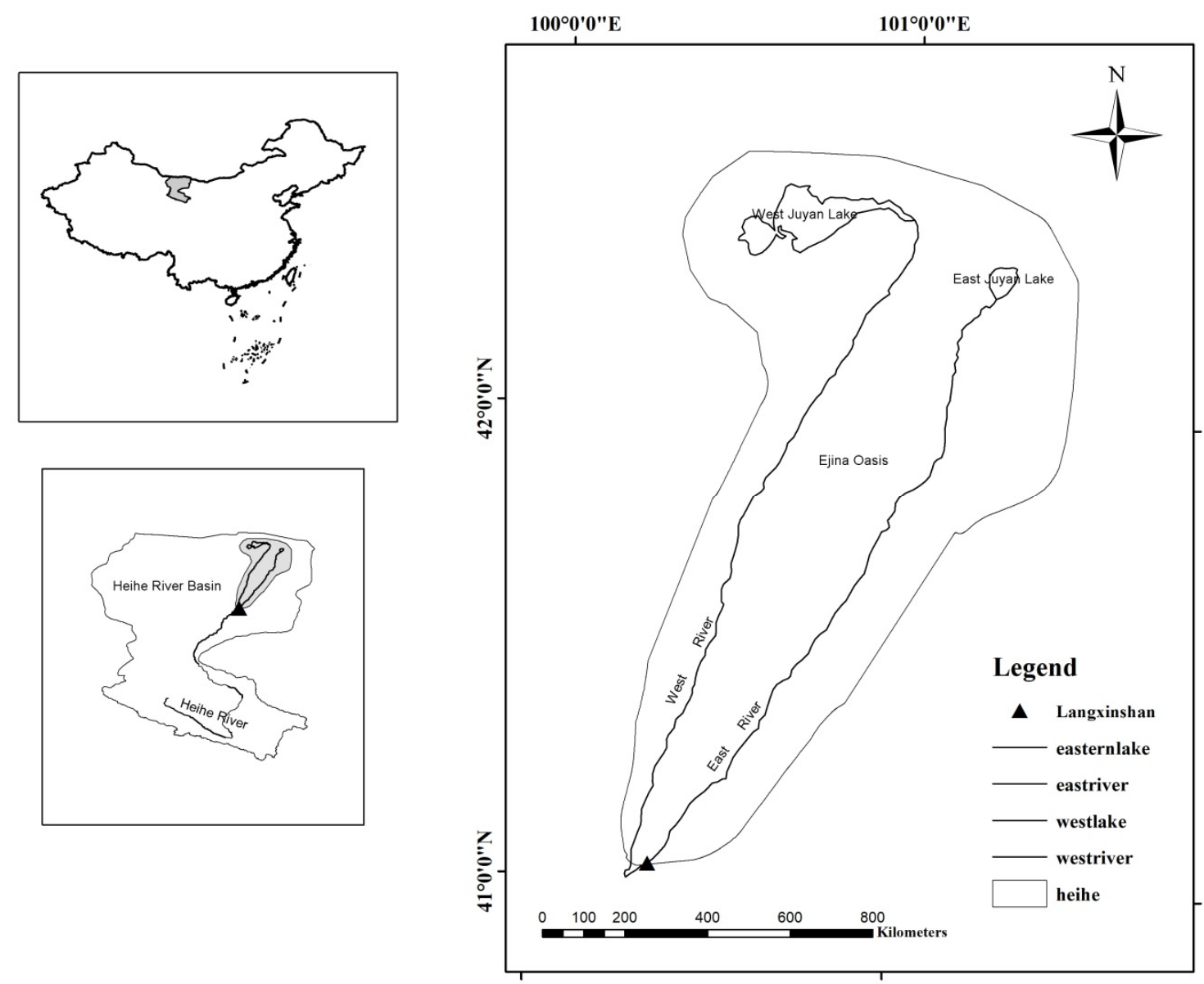

Figure 1. Illustrative map of the Ejina Oasis.

\subsection{The Period of Analysis}

In this study, the current year was 2014, and the total area and the artificial area of the Ejina Oasis were obtained from the data interpreted by remote sensing in 2014. The selection period of other parameters was determined according to the research needs and different purposes. The details are as follows:

Firstly, data from 2006 to 2016 were selected for the area of the Ejina artificial oasis to illustrate the pressure of the oasis scale, especially the expansion of the artificial oasis scale, on local water resources in recent years, emphasizing the importance and urgency of suitable scale research in the terms of factuality. Secondly, the research results of Feng [29] were used for the different water resources with different guarantee rates, which were calculated through the historical data of many years. These theoretical values can guide the future plan for a long period. Similarly, the selection of precipitation time series with different guarantee rates is also the same. The results can guide the future plan for a long period. Thirdly, using the annual classification method to calculate the minimum ecological water demand in the river course required the long time series data to find a typical year as the basic year of river ecological base flow. Fourthly, because the current year of this paper was 2014, the comprehensive influence coefficient of plants was obtained by adding the area weight of 2014 on the basis of the experimental results of Liu's research [30].

\subsection{Methods}

The present study can be divided into two categories: the water balance method and the water-heat balance method. These two methods can evaluate the stability of oasis development from complementary perspectives and, in combination, determine the suitable scale of an oasis. In this 
study, these two methods are proposed to quantitatively estimate the suitable scale of the Ejina Oasis and to evaluate the stability of the oasis scale.

\subsubsection{Water Balance Method}

Few researches have adopted the water balance method to investigate the suitable scale of oases. However, extant representative works are Chen [31] and Chen et al. [32]. The specific methods are as follows:

The difference $(\Delta H(\mathrm{~mm}))$ between the actual annual water resource availability per oasis area and the annual ecological water demand is taken as the water index to evaluate the suitability of the existing oasis area. The area of an oasis that can be expanded or needs to be reduced on the basis of the existing oasis scale is defined as $\Delta S\left(\mathrm{~km}^{2}\right)$. The calculation formulas of the suitable oasis area, determined by the actual annual available water resource, are as follows:

$$
\begin{gathered}
\Delta S=S \times \Delta H / H^{\prime} \\
\Delta H=H-H^{\prime} \\
S^{\prime}=S+\Delta S \\
H=\frac{R \times r_{n}}{S} \times 10^{-1}+P
\end{gathered}
$$

where $S^{\prime}$ is the suitable scale of an oasis in $\mathrm{km}^{2}$; $S$ is the existing oasis area in $\mathrm{km}^{2}$; $H$ is the actual annual water resource availability per oasis area in $\mathrm{mm} ; H^{\prime}$ is the annual ecological water demand in $\mathrm{mm} ; R$ is annual runoff in $10^{8} \mathrm{~m}^{3} ; r_{n}$ is the net utilization rate of annual runoff; and $P$ is precipitation in $\mathrm{mm}$.

\subsubsection{Water-Heat Balance Method}

Combined with the actual situation of an oasis in the Keriya River Basin, Ling et al. [18] re-adjusted the $H_{0}$ index in order to evaluate the oasis water-heat balance proposed by Wang et al. [16] based on the principle of water-heat balance. $H_{0}$ is the "greenness" of the oasis under a certain water resource guarantee, which can reflect the degree of oasis water resource quantity to oasis scale change, and can be used as an index to determine whether or not the oasis is stable. The larger the $H_{0}$ value, the less the stress of water on the green ecology of the oasis and the more stable the oasis, and vice versa. In this study, the stability of the Ejina Oasis in the lower reaches of the Heihe River was evaluated by referring to the classification criteria of oasis stability proposed by Ling et al. [18] (Table 1). The suitable oasis scale under different stability levels was then calculated.

Table 1. Classification of oasis stability.

\begin{tabular}{ccc}
\hline Level & $\boldsymbol{H}_{\mathbf{0}}$ & Evaluation of Oasis Scale \\
\hline Very stable & $>0.75$ & Possesses development potential \\
Stable & $0.50-0.75$ & Safety level is satisfactory, but with less development potential \\
Metastable & $0.20-0.50$ & Does not possess development potential \\
Unstable & $<0.20$ & The oasis must be scaled down to maintain stability \\
\hline
\end{tabular}

The calculation model of index $H_{0}$ to evaluate the oasis water heat balance is as follows:

$$
H_{0}=\frac{W-W_{0}}{\left(E T_{0}-P\right) k_{p} A}
$$


Therefore, the calculation model of the suitable size of the oasis is:

$$
\begin{gathered}
A=\frac{W-W_{0}}{\left(E T_{0}-P\right) k_{p} H_{0}} \\
k_{p}=\sum_{i=1}^{7} k_{i}\left(\frac{S_{i}}{\sum_{i=1}^{7} S_{i}}\right)
\end{gathered}
$$

where $A$ is the area of the oasis in $\mathrm{km}^{2}$ and contains artificial and natural oases; $W$ is the total amount of available water resources in the basin, in $10^{8} \mathrm{~m}^{3} ; W_{0}$ is the annual water demand for industrial water, domestic water, and river ecological environment in the basin, in $10^{8} \mathrm{~m}^{3} ; E T_{0}$ is the reference crop evapotranspiration calculated by the Penman formula [33] in $\mathrm{mm} ; k_{p}$ is the comprehensive influence coefficient of plants in the basin, which is a parameter reflecting the influence of plant biological characteristics on water demand and can be calculated by the vegetation coefficients $\left(k_{i}\right)$ of different vegetation with an area weighted average; $i$ represents seven different vegetation types; vegetation coefficients $\left(k_{i}\right)$ is the coefficient obtained by dividing the diving evaporation with vegetation cover by the diving evaporation without vegetation cover, which is usually determined by experiments. This paper adopts Liu's research results [30]; $S_{i}$ is the area of different vegetation types.

\subsubsection{The Annual Classification Method}

The annual classification method [34] is utilized to estimate the minimum ecological water demand in the river course. First, the anomaly percentage method was used to classify the years of high-, normal-, and low-flow, and then the years with the closest anomaly percentage to $-20 \%$ were taken as typical years. Moreover, the driest month flow in typical years was taken as the ecological base flow, and then converted into annual runoff, which constituted the minimum ecological water demand. The formula for calculating the percentage of anomaly is:

$$
E=\frac{Q_{i}-Q_{n}}{Q_{n}} \times 100 \%
$$

where $E$ is the percentage of annual runoff anomaly of the section in $\%$; $Q_{i}$ is the average annual runoff of the year $i$, in $10^{8} \mathrm{~m}^{3}$; and $Q_{n}$ is the multi-year average runoff of the section in $10^{8} \mathrm{~m}^{3}$.

The classification standards of high-, normal-, and low-flow years are shown in Table 2.

Table 2. Classification standards of high-, normal-, and low-flow years.

\begin{tabular}{ccccc}
\hline \multirow{2}{*}{ Years } & $\begin{array}{c}\text { High-Flow } \\
\text { Years }\end{array}$ & $\begin{array}{c}\text { Normal-Flow } \\
\text { Years }\end{array}$ & Partial Low-Flow Years & Special Low-Flow Years \\
\cline { 4 - 5 } $\begin{array}{c}\text { Anomaly } \\
\text { percentage } E(\%)\end{array}$ & $E>10$ & $-10 \leq E \leq 10$ & $-20<E \leq-10$ & $E<-20$ \\
\hline
\end{tabular}

Note: From "the standard of hydrological terms and symbols" (GB/T50095-98).

\section{Results}

\subsection{Area of Artificial Oasis in Ejina}

The oasis area of Ejina in Inner Mongolia is a large-scale original natural ecological area, and, thus, has special ecological protection and is not suitable for agricultural development. Therefore, $60 \%$ of the suitable oasis area of the Ejina Oasis cannot be used to determine the cultivated land area according to water resources. Statistical data show that the irrigated area of farmland in the Ejina Oasis is only $44.67 \mathrm{~km}^{2}$, forest and fruit is $38.20 \mathrm{~km}^{2}$, and grassland is $730.67 \mathrm{~km}^{2}$. The total of irrigated farmland, 
forest, fruit, and grassland in the Ejina Oasis is $813.54 \mathrm{~km}^{2}$, which constitutes the area of the current artificial oasis. According to the analysis of the annual change of the artificial oasis area in Ejina from 2006 to 2016, except for the sharp decline in 2011, all other years exhibited an upward trend (Figure 2), with an increase of nearly 3.4 times in 10 years. The expansion of the scale of artificial oasis leads to the increase of the demand for water resources, which inevitably brings the contradiction between the supply and demand of water resources, so it is necessary and urgent to study the appropriate scale of oasis.

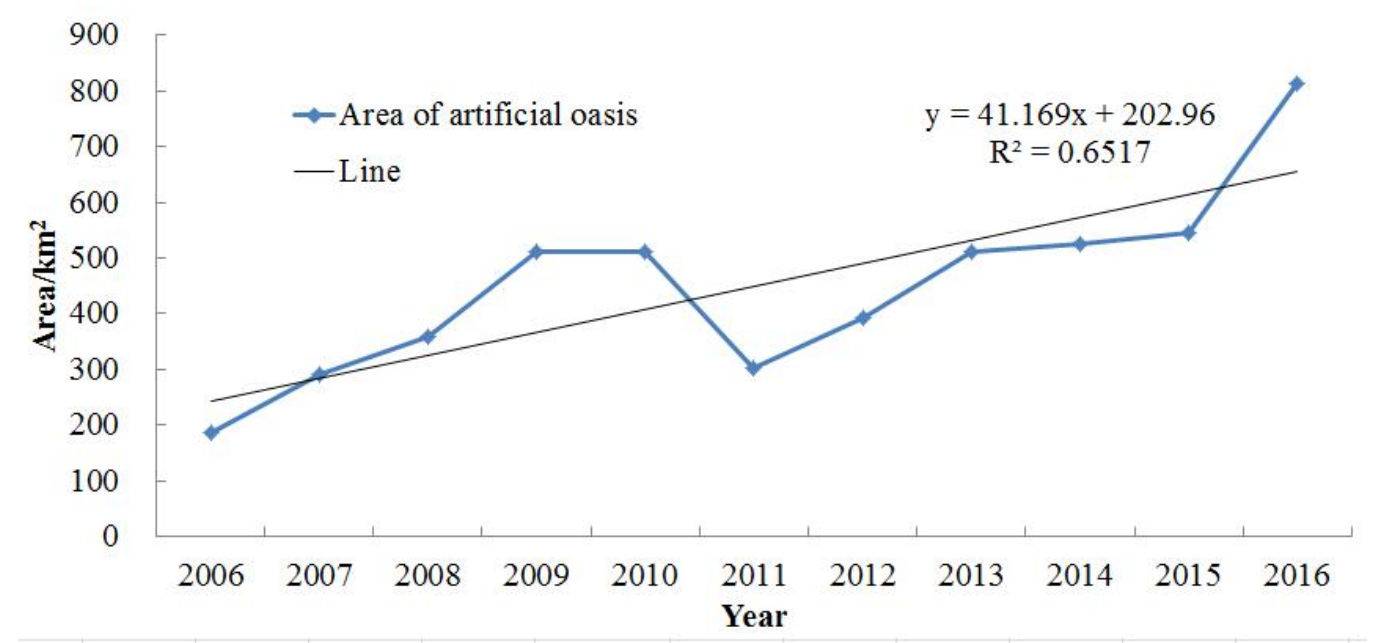

Figure 2. Changes of the artificial oasis area of Ejina.

\subsection{Water Resource Quantity at Different Guarantee Rates}

Feng et al. [29] studied and determined the water distribution of different guarantee rates in the lower reaches of the Heihe River. When the water inflow guarantee rate was $25 \%, 50 \%$, and $75 \%$, the corresponding water yield of Langxinshan was $5.9 \times 10^{8} \mathrm{~m}^{3}, 4.9 \times 10^{8} \mathrm{~m}^{3}$, and $3.6 \times 10^{8} \mathrm{~m}^{3}$, respectively. The Heihe River is the only river entering Ejina. It flows through the Zhengyixia, Dingxin, and Dongfengchang, to the Langxinshan. After entering the Ejina Oasis through the Langxinshan hydrologic station, it is divided into the East River, West River, and East Canal [29]. Therefore, the runoff of the Langxinshan hydrologic station can be considered as the total surface water resources of the Ejina Oasis.

\subsection{Precipitation at Different Guarantee Rates}

The average annual precipitation from 1981 to 2014 in Ejina was $32.45 \mathrm{~mm}$. The maximum value of $77.3 \mathrm{~mm}$ occurred in 1995, while the minimum value of $7 \mathrm{~mm}$ occurred in 1983. Although the average precipitation exhibited a slight upward trend, the trend was non-obvious (Figure 3). The annual precipitation frequency curve was drawn by using the principle of the suitable line method (Pearson III distribution curve) (Figure 4). The values corresponding to the frequencies of $25 \%, 50 \%$, and $75 \%$ were found, respectively, from the annual precipitation frequency curve-i.e., the designed values of annual precipitation at different levels. The designed annual precipitation of high-flow years $(P=25 \%)$, normal-flow years $(\mathrm{P}=50 \%)$, and low-flow years $(\mathrm{P}=75 \%)$ could be obtained as $43.97 \mathrm{~mm}, 28.17 \mathrm{~mm}$, and $16.30 \mathrm{~mm}$, respectively. 


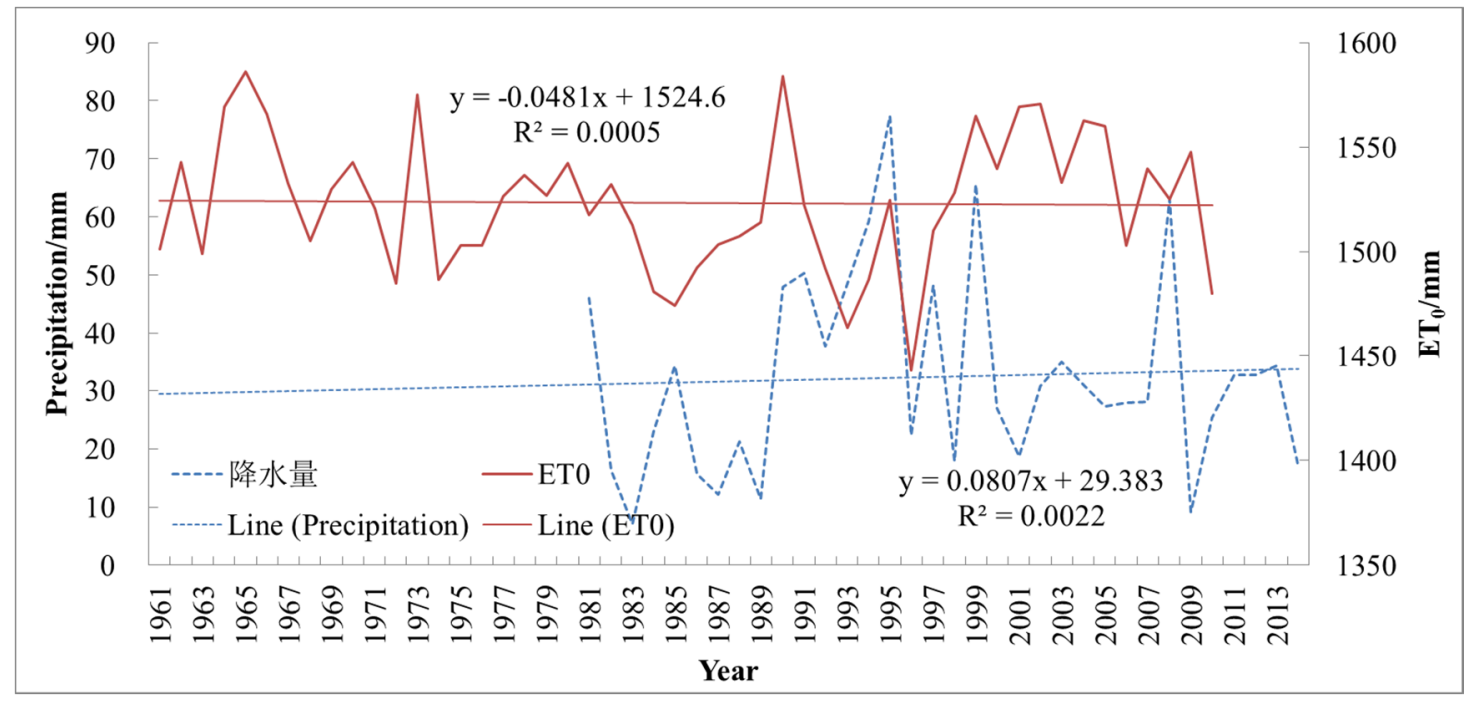

Figure 3. Annual precipitation and reference crop evapotranspiration in the Ejina Oasis.

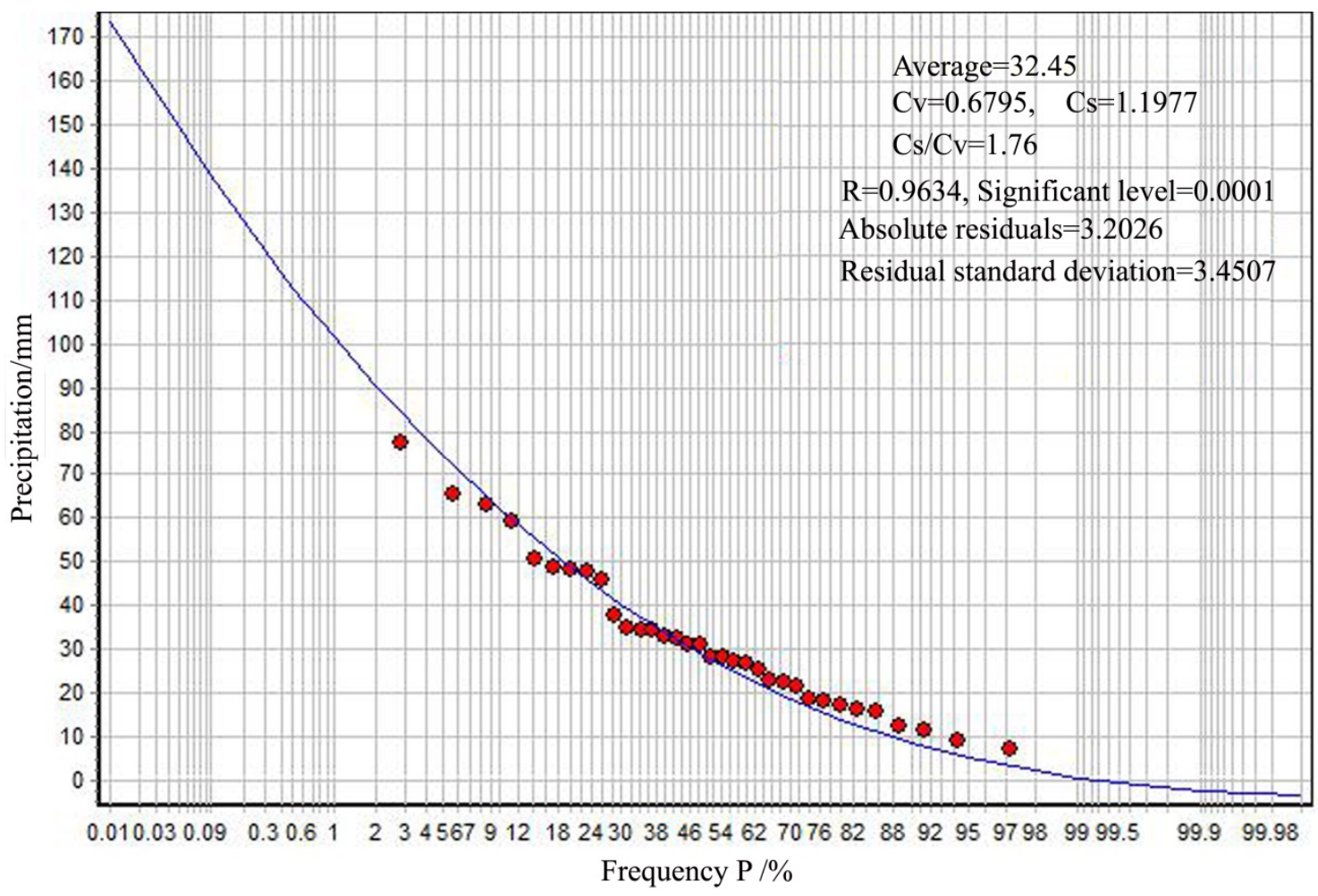

Figure 4. Pearson III frequency distribution curve for annual precipitation.

\subsection{Reference Crop Evapotranspiration}

Li et al. [33] estimated the spatial and temporal distribution of reference crop evapotranspiration in arid regions by using the Penman model. From 1961 to 2010, the multi-year average of the reference crop evapotranspiration of Ejina was $1523.37 \mathrm{~mm}$, exhibiting a slight downward—but non-obvious—-trend (Figure 3).

\subsection{Comprehensive Influence Coefficient of Plants}

Liu [30] combined meteorological data and remote-sensing images to investigate the vegetation coefficients of seven types of vegetation in the Heihe River Basin, including forestland, sparse 
woodlands, shrubland, desert, farmland, high-cover grassland, and medium-cover grassland, and calculated the vegetation coefficients of different vegetation growth periods. In the current paper, through interpreting the remote-sensing images of the core area of the Ejina Oasis in 2014, seven types of vegetation areas were obtained. The crop coefficients of the different vegetation were then weighted and averaged according to area. The comprehensive influence coefficient of plants in the Ejina Oasis was calculated to be 0.3615 by Formula 7 . The comprehensive influence coefficient of plants was closest to the desert, indicating that the desert area in this region accounted for the majority, as seen in Table 3.

Table 3. Statistics of areas of different vegetation in the core area of the Ejina Oasis.

\begin{tabular}{ccc}
\hline Vegetation Type & Area/km & Coefficient of Vegetation \\
\hline Forestland & 188.8848 & 0.7833 \\
Sparse woodlands & 1152.1400 & 0.6500 \\
Shrubland & 0.1395 & 0.5433 \\
Desert & 58447.1600 & 0.3533 \\
Farmland & 122.2254 & 0.6433 \\
High-cover grassland & 148.3884 & 0.5767 \\
Medium-cover grassland & 0.0855 & 0.3500 \\
\hline
\end{tabular}

\subsection{Ecological Environmental Water Demand of River Course}

The annual anomaly percentage was calculated by using the average runoff data of the Langxinshan Hydrologic Station from 1988 to 2015 (Table 4). According to the standard of Table 2, each year could be defined as a high-flow year, normal-flow year, or low-flow year. During 28 years, the years of 1991, 1992, 1994, 1995, 1997, 1999-2001, and 2004 were special low-flow years. The years of 1988, 1993, 1996, 1998, 2002, 2005, and 2010 were normal-flow years. The others were high-flow years. In 2004, the annual runoff of the Langxinshan Hydrologic Station was $3.93 \times 10^{8} \mathrm{~m}^{3}$. Because there were no monthly runoff data, the monthly runoff distribution proportion of the Yingluoxia Hydrology Station in 2004 was used to estimate the monthly runoff data of the Langxinshan Hydrologic Station. The results showed that the minimal runoff appeared in February and December. Converted into flow data, it was found that the minimum flow was only $3.58 \mathrm{~m}^{3} / \mathrm{s}$, which appeared in December-i.e., the ecological base flow in the river course of the Langxinshan Hydrologic Station. Moreover, the annual minimum ecological water demand was $1.13 \times 10^{8} \mathrm{~m}^{3}$, which was taken as the river ecological environment water demand in the core area of the Ejina Oasis.

Table 4. Classification of high-, normal-, and low-flow years from 1988 to 2015.

\begin{tabular}{cccccc}
\hline Year & $\begin{array}{c}\text { Percentage of } \\
\text { Annual Runoff } \\
\text { Anomaly } \boldsymbol{E} / \%\end{array}$ & Type & Year & $\begin{array}{c}\text { Percentage of } \\
\text { Annual Runoff } \\
\text { Anomaly } \boldsymbol{E} / \%\end{array}$ & Type \\
\hline 1988 & 4.13 & Normal-flow year & 2002 & -4.72 & Normal-flow year \\
1989 & 112.18 & High-flow year & 2003 & 40.86 & High-flow year \\
1990 & 14.54 & High-flow year & 2004 & -22.79 & Special low-flow year \\
1991 & -44.99 & Special low-flow year & 2005 & -3.73 & Normal-flow year \\
1992 & -64.05 & Special low-flow year & 2006 & 20.63 & High-flow year \\
1993 & 1.77 & Normal-flow year & 2007 & 27.50 & High-flow year \\
1994 & -47.54 & Special low-flow year & 2008 & 37.33 & High-flow year \\
1995 & -25.15 & Special low-flow year & 2009 & 33.40 & High-flow year \\
1996 & -1.18 & Normal-flow year & 2010 & -5.11 & Normal-flow year \\
1997 & -58.55 & Special low-flow year & 2011 & 14.15 & High-flow year \\
1998 & 2.95 & Normal-flow year & 2012 & 11.79 & High-flow year \\
1999 & -36.74 & Special low-flow year & 2013 & 31.63 & High-flow year \\
2000 & -44.60 & Special low-flow year & 2014 & 27.90 & High-flow year \\
2001 & -48.13 & Special low-flow year & 2015 & 28.29 & High-flow year \\
\hline
\end{tabular}




\subsection{The Suitable Scale of Oasis}

\subsubsection{The Suitable Scale of Artificial Oasis Estimated by the Water Balance Method}

Chen [31] calculated the net utilization rate of annual runoff in the Heihe River Basin to be $59.0 \%$. The basic data were from the 1:50,000 series maps of soil and water resources compiled by the Lanzhou Institute of Desert Research, Chinese Academy of Sciences, from 1980-1984. This was determined according to the water diversion rate, canal system utilization rate, and groundwater natural recharge resources in recent years in order to calculate the actual annual groundwater resources of Ejina used for agriculture, forestry, and animal husbandry-i.e., the actual annual irrigation water amount. The actual annual irrigation water layer thickness could be obtained by distributing the actual annual groundwater resources on the existing artificial oasis area equally. Due to the flat terrain of the Ejina Oasis, precipitation rarely forms surface runoff and flows along the river gully, most of which can be infiltrated in soil. Due to rare precipitation, only the soil tillage layer and forest and grass root layer could be infiltrated. Therefore, the actual annual water resource that plays a role in agriculture, forestry, and animal husbandry production on the oasis can be considered as the actual annual irrigation water layer thickness plus precipitation in the corresponding period (excluding direct evaporation) [31]. Based on the above calculation, the actual annual water resources in the Ejina Oasis were obtained under different water inflow guarantee rates (Table 5).

Table 5. Actual annual water resources in the Ejina artificial oasis under different water inflow guarantee rates.

\begin{tabular}{ccccccccc}
\hline $\begin{array}{c}\text { Rates } \\
/ \%\end{array}$ & $\begin{array}{c}\text { AR/ } \\
\mathbf{1 0} \mathbf{m}^{\mathbf{3}}\end{array}$ & $\begin{array}{c}\text { NUR } \\
/ \%\end{array}$ & $\begin{array}{c}\text { AIW } \\
/ \mathbf{1 0}^{\mathbf{8}} \mathbf{m}^{\mathbf{3}}\end{array}$ & $\begin{array}{c}\text { OA } \\
/ \mathbf{k m}^{\mathbf{2}}\end{array}$ & $\begin{array}{c}\overline{\mathbf{A I W}} \\
\mathbf{m}^{\mathbf{3}} / \mathbf{m}^{\mathbf{2}}\end{array}$ & $\begin{array}{c}\text { Thickness } \\
/ \mathbf{m m}\end{array}$ & $\begin{array}{c}\text { AP } \\
/ \mathbf{m m}\end{array}$ & $\begin{array}{c}\text { AWR } \\
/ \mathbf{m m}\end{array}$ \\
\hline 25 & 5.9 & 59 & 3.481 & 813.53 & 0.42788 & 427.88 & 43.97 & 472 \\
50 & 4.9 & 59 & 2.891 & 813.53 & 0.35536 & 355.36 & 28.17 & 384 \\
75 & 3.6 & 59 & 2.124 & 813.53 & 0.26108 & 261.08 & 16.30 & 277 \\
\hline
\end{tabular}

Note: Rates represent 'Water inflow guarantee rates'; AR represents 'Actual annual runoff'; NUR represents 'Net utilization rate of annual runoff'; AIW represents 'Actual annual amount of irrigation water'; OA represents 'Actual oasis area'; AIW represents 'Average annual amount of irrigation water'; Thickness represents 'Annual irrigation water layer thickness'; AP represents 'Annual precipitation'; AWR represents 'Annual actual water resources.'

The oasis water requirement was based on the existing research results of Jinta County, which is close to Ejina Banner and has similar climatic conditions [31]. It can be seen from Table 6 that there was a difference between actual annual water resources and oasis water demand. In high-, normal-, and low-flow years, the area of the artificial oasis should be reduced by $45.73,189.53$, and $362.20 \mathrm{~km}^{2}$, respectively. The suitable artificial oasis area was $767.80,624.00$, and $451.33 \mathrm{~km}^{2}$, respectively.

Table 6. Area required for expansion or reduction of the Ejina artificial oasis and suitable area.

\begin{tabular}{ccccc}
\hline Rates/\% & OWR/mm & Difference/mm & $\mathbf{E}(+)$ or $\mathbf{R}(-) / \mathbf{k m}^{\mathbf{2}}$ & $\mathbf{S A} / \mathbf{k m}^{\mathbf{2}}$ \\
\hline 25 & 500 & -28 & -45.73 & 767.80 \\
50 & 500 & -116 & -189.53 & 624.00 \\
75 & 500 & -223 & -362.20 & 451.33 \\
\hline
\end{tabular}

Note: Rates represents 'Water inflow guarantee rates'; OWR represents 'Oasis water requirement'; Difference represents 'Difference between water supply and demand in the oasis'; $\mathrm{E}(+)$ or $\mathrm{R}(-)$ represents 'Area required for expansion (+) or reduction (-) of the Ejina artificial oasis'; SA represents 'Suitable area of artificial oasis.'

\subsubsection{Suitable Scale of Oasis Estimated by the Water-Heat Balance Method}

By interpreting the remote-sensing images of the core area of the Ejina Oasis in 2014, the area of the Ejina Oasis was $1612 \mathrm{~km}^{2}$, which included the artificial oasis and the natural oasis. According to Equations (5) and (6), the stability indexes were 0.5 and 0.75 , respectively. The suitable scale range of the Ejina Oasis was then calculated, as well as the stability under the current oasis scale (Table 7). 
Table 7. Suitable scale and stability of the Ejina Oasis.

\begin{tabular}{|c|c|c|c|c|c|c|c|c|}
\hline Year Type & $\begin{array}{l}\text { TAWR } \\
/ 10^{8} \mathrm{~m}^{3}\end{array}$ & $\begin{array}{c}E T_{0} \\
/ \mathrm{mm}\end{array}$ & $\begin{array}{c}P \\
/ \mathrm{mm}\end{array}$ & $\begin{array}{l}\mathrm{COA} \\
/ \mathrm{km}^{2}\end{array}$ & $\begin{array}{l}\mathrm{SSO} \\
/ \mathrm{km}^{2}\end{array}$ & $H_{0}$ & $\begin{array}{c}\text { OAR } \\
\left(H_{0}=0.5\right)\end{array}$ & $\begin{array}{c}\text { OAR } \\
\left(H_{0}=0.75\right)\end{array}$ \\
\hline High-flow year & 5.9 & 1523.37 & 43.97 & 1612 & $1174-1762$ & 0.55 & 150 & -438 \\
\hline Normal-flow year & 4.9 & 1523.37 & 28.17 & 1612 & 915-1373 & 0.43 & -239 & -697 \\
\hline Low-flow year & 3.6 & 1523.37 & 16.30 & 1612 & $590-885$ & 0.27 & -727 & -1022 \\
\hline
\end{tabular}

Note: TAWR represents 'Total available water resources'; COA represents 'Current oasis area'; SSO represents 'Suitable scale of oasis'; OAR $\left(H_{0}=0.5\right)$ represents 'Oasis area to be reduced when $H_{0}=0.5$ '; OAR $\left(H_{0}=0.75\right)$ represents 'Oasis area to be reduced when $H_{0}=0.75$ '; for the last two columns, negative values indicate the oasis area to be reduced, and positive values indicate the oasis area to be expanded.

According to Table 7, the suitable scale of the Ejina Oasis in high-flow years was $1174-1762 \mathrm{~km}^{2}$, while the current oasis scale is $1612 \mathrm{~km}^{2}$. In addition, the stability index was 0.55 , which indicates that in a high-flow year, the total water quantity of Ejina could meet the water consumption of the artificial oasis and the natural oasis, but the stability index was close to the lower-limit critical value of stability. In a normal-flow year, the suitable scale of the Ejina Oasis was $915-1373 \mathrm{~km}^{2}$, which is smaller than the current oasis scale. Moreover, the stability index was 0.43 , which was close to the upper-limit critical value of sub-stability, indicating that it did not possess development potential. In a low-flow year, the stability index decreased to 0.27 , and its suitable oasis scale was determined as $590-885 \mathrm{~km}^{2}$, which is much smaller than the current oasis scale. From the stability index, when $H_{0}$ was 0.5 , the oasis was in a critical stable state, and the suitable scale of the Ejina Oasis was $1762 \mathrm{~km}^{2}, 1373 \mathrm{~km}^{2}$, and $885 \mathrm{~km}^{2}$ in high-, normal-, and low-flow years, respectively. When $H_{0}$ was 0.75 , the oasis was in a stable state, and the suitable scale of the Ejina Oasis was $1174 \mathrm{~km}^{2}, 915 \mathrm{~km}^{2}$, and $590 \mathrm{~km}^{2}$ in high-, normal-, and low-flow years, respectively.

\subsubsection{The Suitable Scale of Natural Oasis}

According to the water delivery of the main stream of the Heihe River over the years, the minimum annual water discharge of the Langxinshan Hydrologic Station was $2.64 \times 10^{8} \mathrm{~m}^{3}$, and the maximum was $9.83 \times 10^{8} \mathrm{~m}^{3}$. In particular, the amount of water discharged in the last 10 years was close to or above $4.9 \times 10^{8} \mathrm{~m}^{3}$. Therefore, it was concluded that the inflow of water was relatively abundant, and most years could reach the level of high- and normal-flow years. The suitable scale of oasis should be controlled at $915-1762 \mathrm{~km}^{2}$, while the suitable scale of artificial oasis should be controlled at $624.00-767.80 \mathrm{~km}^{2}$. The suitable scale of the natural oasis could be further obtained as $291-994.2 \mathrm{~km}^{2}$.

\section{Conclusions and Discussion}

According to Feng et al. [29], the total surface water resources in the Ejina Oasis were $5.9 \times 10^{8} \mathrm{~m}^{3}$, $4.9 \times 10^{8} \mathrm{~m}^{3}$, and $3.6 \times 10^{8} \mathrm{~m}^{3}$ in high-flow years $(\mathrm{P}=25 \%)$, normal-flow years $(\mathrm{P}=50 \%)$, and low-flow years $(\mathrm{P}=75 \%)$, respectively. According to the statistical analysis of the average annual precipitation of Ejina from 1981 to 2014, the designed annual precipitation of high-, normal-, and low-flow years was $43.97 \mathrm{~mm}, 28.17 \mathrm{~mm}$, and $16.30 \mathrm{~mm}$, respectively. The minimum ecological environmental water requirement of the river course in the core area of the Ejina Oasis was estimated to be $1.13 \times 10^{8} \mathrm{~m}^{3}$ by using the annual classification method.

According to the calculation of the water balance method, the suitable scale of the Ejina artificial oasis was $767.80,624.00$, and $451.33 \mathrm{~km}^{2}$ in high-, normal-, and low-flow years, respectively, while the current area of the artificial oasis is $813.53 \mathrm{~km}^{2}$. This means that the agricultural and forest area relying on irrigation needs to decrease to $45.73,189.53$, and $362.20 \mathrm{~km}^{2}$, respectively, in different flow level years.

According to the calculation of the water-heat balance method, in high-flow years, the suitable scale of the Ejina Oasis was $1174-1762 \mathrm{~km}^{2}$, and the stability index of the current oasis is 0.55 . In normal-flow years, the suitable scale of the Ejina Oasis was $915-1373 \mathrm{~km}^{2}$, and the stability index of the current oasis is 0.43 . In low-flow years, the suitable scale of the Ejina Oasis was $590-885 \mathrm{~km}^{2}$, and the stability 
index of the current oasis decreased to 0.27 . Since the current oasis scale is $1612 \mathrm{~km}^{2}$, only when the oasis stability index was required to be 0.5 in high-flow years could the area of the Ejina Oasis be appropriately expanded by $150 \mathrm{~km}^{2}$. The oasis area must be reduced under the other frequencies and any stability index. In spite of the annual runoff of the Langxinshan Hydrologic Station in the last 10 years being close to, or reaching, the standard of high-flow years, the oasis stability index could only remain at approximately 0.5 . In order to further improve the stability of the oasis, it remains necessary to control the scale of the oasis to cope with the water resource shortage of the oasis brought about by water resource instability under climate change.

Based on the research results of the artificial oasis scale and the suitable scale of the whole oasis, the paper further estimated that the suitable scale of the natural oasis was 291-994.2 $\mathrm{km}^{2}$.

Arid and semi-arid regions constitute approximately $40 \%$ of the world's total land area, with sparse precipitation and scarce water resources. If global greenhouse gas emissions continue to rise, the expansion of arid and semi-arid regions around the world will accelerate, accounting for more than 50 percent of the world's land surface by the end of the 21st century [35]. Arid and semi-arid regions generally exhibit basic landscape configurations, with deserts as the landscape matrix and oases as the landscape mosaic. As a unique ecological unit, oases are the basic site in which people live, produce, and develop in arid and semi-arid areas. Every continent in the world has a distribution of oases, and they have played key roles in the formation of human civilization. In China, oases, which account for $5 \%$ of the land area, feed $95 \%$ of the population [36]. Therefore, this study is not only a reference for appropriate scale studies of other oases in China, but also has practical significance for arid and semi-arid regions globally. The results of oasis suitable scale studies are critical for the rational allocation of limited water resources, especially in areas of severe water shortage. With great increases of population and the continuous expansion of human living space, water consumption in oasis areas will increase and the stability of oases will be reduced. Therefore, it is of vital importance for social development to accurately determine the optimal size of oases to guide the rational use of water resources.

Author Contributions: Investigation, S.Z.; Supervision, A.F.; Writing—original draft, Z.Y.; Writing—review \& editing, Y.Y. All authors have read and agreed to the published version of the manuscript.

Funding: This work was supported by the Strategic Priority Research Program of Chinese Academy of Sciences (XDA19030204) and the National Natural Science Foundation of China (U1803101, 91425301).

Acknowledgments: We are grateful to Jake Carpenter, who provided language help. We also thank the editors and anonymous reviewers for their comments and suggestions on the article.

Conflicts of Interest: The authors declare no conflict of interest.

\section{References}

1. Chen, Y.N. Study on Ecological Hydrology of Tarim River Basin in Xinjiang; Science Press: Beijing, China, 2010. (In Chinese)

2. Fan, Z.L.; Ma, Y.J.; Wang, R.H.; Ji, F.; Zhang, L.Y. Ecosystem types in the continental river watershed of arid area and the manage?mental approaches. J. Desert Res. 2000, 12, 293-296. (In Chinese)

3. Wang, Y.B.; Feng, Q.; Si, J.H.; Su, Y.H.; Chang, Z.Q.; Xi, H.Y. The changes of vegetation cover in Ejina oasis based on water resources redistribution in Heihe River. Environ. Earth Sci. 2011, 64, 1965-1973.

4. Liu, Y.S. Introduction to land use and rural sustainability in China. Land Use Policy 2018, 74, 1-4. [CrossRef]

5. Chen, Y.N. Arid Desert Ecosystems and Sustainable Management; Science Press: Beijing, China, 2009. (In Chinese)

6. Huang, J.F.; Wang, R.H.; Zhang, H.Z. Analysis of patterns and ecological security trend of modern oasis landscapes in Xinjiang, China. Environ. Monit. Assess. 2007, 134, 411-419. [CrossRef] [PubMed]

7. Luedeling, E.; Buerkert, A. Effects of land use changes on the hydrological sustainability of mountain oases in northern Oman. Plant Soil 2008, 304, 1-20. [CrossRef]

8. Zhang, Q.Q.; Xu, H.L.; Li, Y.; Fan, Z.L.; Zhang, P.; Yu, P.J.; Ling, H.B. Oasis evolution and water resource utilization of a typical area in the inland river basin of an arid area: A case study of the Manas River valley. Environ. Earth Sci. 2012, 66, 683-692. [CrossRef] 
9. Kawy, W.A.; Darwish, K.M. Assessment of optimum land use and water requirements for agricultural purpose in some soils South Paris Oasis, Western Desert, Egypt. Arab. J. Geosci. 2014, 7, 4043-4058. [CrossRef]

10. Massone, H.; Martinez, D.; Vich, A.; Londoño, M.Q.; Trombotto, D.; Grondona, S. Snowmelt contribution to the sustainability of the irrigated Mendoza's Oasis, Argentina: An isotope study. Environ. Earth Sci. 2016, 75, 520. [CrossRef]

11. Xue, J.; Gui, D.W.; Lei, J.Q.; Sun, H.W.; Zeng, F.J.; Mao, D.L.; Zhang, Z.W.; Jin, Q.; Liu, Y. Oasis microclimate effects under different weather events in arid or hyper arid regions: A case analysis in southern Taklimakan desert and implication for maintaining oasis sustainability. Theor. Appl. Climatol. 2019, 137, 89-101. [CrossRef]

12. Tenza, A.; Martínez-Fernández, J.; Pérez-Ibarra, I.; Giménez, A. Sustainability of small-scale social-ecological systems in arid environments: Trade-off and synergies of global and regional change. Sustain. Sci. 2019, 14, 791-807. [CrossRef]

13. Li, Q.K.; Huang, F.G.; Luo, Y.L.; Zhang, X.; Sun, J.; Hu, Y.W. Study on ecological water requirements for restoring the oasis in Ejina Region. J. Water Resour. Water Eng. 2006, 17, 9-13. (In Chinese)

14. Gong, B.; Wan, L.; Hu, F.S.; Jin, X.M.; Liang, S.H. Degradation and controlling factors of the Ejina Oasis in the downstream Heihe River. Hydrogeol. Eng. Geol. 2006, 1, 58-61. (In Chinese)

15. Hu, S.J.; Song, Y.D.; Tian, C.Y.; Li, Y.T.; Li, X.C.; Chen, X.B. Suitable scale of Weigan River plain oasis. Sci. China Ser. D Earth Sci. 2007, 50 (Suppl. 1), 56-64. [CrossRef]

16. Wang, G.X.; Cheng, G.D.; Shen, Y.P. Dynamic tendency of arid oasis under the influence of water resources decrease-A case study of Ejina oasis in Heihe River Basin. Chin. J. Appl. Ecol. 2002, 13, 564-568. (In Chinese)

17. Li, W.H.; Li, F.; Chen, Z.S.; Wang, Y.; Li, B.M. Analysis of driving force of water consumption in plain and suitable scale of oasis in Hotan River Basin. J. Glaciol. Geocryol. 2011, 33, 1161-1168. (In Chinese)

18. Ling, H.B.; Xu, H.L.; Liu, X.H.; Zhang, Q.Q.; Fu, J.Y.; Bai, Y. Suitable scale of oasis in Keriya River basin, Xinjiang. Adv. Water Sci. 2012, 23, 563-568. (In Chinese)

19. Cao, Z.C.; Wang, X.P.; Li, W.H.; Ye, Z.X.; Guo, B. Suitable scale for oasis in lower reaches of Tarim River. Arid Land Geogr. 2012, 35, 806-814. (In Chinese)

20. Chen, Y.N.; Chen, Z.S. Analysis of oasis evolution and suitable development scale for arid regions: A case study of the Tarim River Basin. Chin. J. Eco Agric. 2013, 21, 134-140. (In Chinese)

21. Ling, H.B.; Xu, H.L.; Fu, J.Y.; Fan, Z.L.; Xu, X.W. Suitable oasis scale in a typical continental river basin in an arid region of China: A case study of the Manas River Basin. Quat. Int. 2013, 286, 116-125. [CrossRef]

22. Lei, Y.; Li, X.Y.; Ling, H.B. Model for calculating suitable scales of oases in a continental river basin located in an extremely arid region, China. Environ. Earth Sci. 2015, 73, 571-580. [CrossRef]

23. Yao, Y.P.; Wahap, H.L.; Fu, J.R. Study on the suitability evaluation of oasis scale in arid area. J. Nat. Sci. Hunan Norm. Univ. 2016, 39, 1-7. (In Chinese)

24. Guo, H.W.; Ling, H.B.; Xu, H.L.; Guo, B. Study of suitable oasis scales based on water resource availability in an arid region of China: A case study of Hotan River Basin. Environ. Earth Sci. 2016, 75, 1-14. [CrossRef]

25. Wang, Z.J.; Wang, H.F.; Lei, Z.D. Stability analysis of oasis in arid region. J. Hydraul. Eng. 2002, 5, 26-30. (In Chinese)

26. Han, Y.; Qi, Y.Z.; Zhou, Y. Discussion on water resource utilization in Ejina Oasis. Inn. Mong. Water Conserv. 2017, 3, 41-42. (In Chinese)

27. Zhang, M.; Wang, S.; Gao, G.; Fu, B.; Ye, Z.; Shen, Q. Exploring responses of lake area to river regulation and implications for lake restoration in arid regions. Ecol. Eng. 2019, 128, 18-26. [CrossRef]

28. Jin, X.M.; Hu, G.C. Vegetation change and estimation of the smallest water demand of Ejina oasis in lower reaches of Heihe River. Adv. Sci. Technol. Water Resour. 2010, 30, 30-36. (In Chinese)

29. Feng, Q.; Si, J.H.; Xi, H.Y. Ecological Water Demand and Ecological Water Quantity Regulation in the Lower Reaches of Heihe River; Science Press: Beijing, China, 2015. (In Chinese)

30. Liu, J. Study on the Vegetation Ecological Water Requirement in the Heihe River Basin based on 3S Technology. Master Thesis, Northwest Agriculture \& Forestry University, Yangling, Shan Xi, China, 2014. (In Chinese).

31. Chen, C.Y. The suitable areas in oasis and cultivated lands and preventive measures against sand disasters in Hexi Corridor. Agric. Res. Arid Areas 1990, 2, 30-37. (In Chinese)

32. Chen, X.B.; Yang, J.S.; Qiao, X.Y.; Liu, C.Q.; Hu, S.J. Determination of fitting cultivated area and disaster reduction-A case study in Weigan River irrigation area. Chin. J. Geol. Hazard Control 2008, 19, 118-123. (In Chinese) 
33. Li, Z.; Chen, Y.; Yang, J.; Wang, Y. Potential evapotranspiration and its attribution over the past 50 years in the arid region of Northwest China. Hydrol. Process. 2014, 28, 1025-1031. [CrossRef]

34. Wei, W.W.; Liu, Z.H.; Feng, J. A study of the estimation of the Hutubi River ecological base flow in the North Slope of the Tianshan Mountains. China Rural Water Hydropower 2017, 6, 92-96. (In Chinese)

35. Huang, J.P.; Yu, H.P.; Guan, X.D.; Wang, G.Y.; Guo, R.X. Accelerated dryland expansion under climate change. Nat. Clim. Chang. 2016, 6, 166-171. [CrossRef]

36. Zhang, Q.; Hu, Y.Q. Oasis effect in arid regions. Chin. J. Nat. 2001, 23, 234-236. (In Chinese)

(C) 2020 by the authors. Licensee MDPI, Basel, Switzerland. This article is an open access article distributed under the terms and conditions of the Creative Commons Attribution (CC BY) license (http://creativecommons.org/licenses/by/4.0/). 